\title{
Tiltrækning, fastholdelse og ledelse af frivillige i idrætsforeninger
}

\author{
Af Jens Holmgren og Ole Friis *)
}

\begin{abstract}
Resumé
Der anvendes i stadig større omfang frivillige i forbindelse med ydelser, der traditionelt har været betalt eller støttet af det offentlige, og stadig flere anvender deres tid som frivillige særligt blandt den voksende gruppe af ældre borgere. Det større udbud af muligheder for at gøre en frivillig indsats på forskellige områder har medført, at nogle af de traditionelle frivillige foreninger har oplevet det vanskeligere at rekruttere frivillige. Men mange ledere i idrætsforeninger har ikke bevidsthed om, at ledelse er vigtig for at få foreningen til at fungere godt, og at der i dag i langt højre grad gælder de samme mekanismer, som der gør på arbejdsmarkedet. Vi argumenterer for, at man som frivillig leder kan skabe resultater, hvis man er bevidst om og bruger tre former for fokus: et indre fokus, fokus på andre og et ydre fokus. Det kan hjælpe den frivillige leder med at agere som en professionel leder, der med passion skal udleve idrætsforeningens mission, omsætte den til en strategi, som kan motivere de frivillige, ved at de udfordres og involveres i beslutningstagningen, så de kan se en mening i det, der foregår, indgå i nye sociale netværk og fællesskaber og samtidig have det sjovt.
\end{abstract}

\section{Emneord}

Ledelse af frivillige, idrætsforeninger, tiltrækning, fastholdelse, motivation

*) Jens Holmgren (jens@business.aau.dk) er ph.d. og lektor. Ole Friis (ole@business.aau.dk) er ph.d. og lektor. Begge er tilknyttet Aalborg University Business School. 


\section{A. Introduktion}

\section{Baggrund}

I de senere år er der opstået en ny tendens i samspillet mellem det civile samfund og det offentlige. Der anvendes i stadig større omfang frivillige i forbindelse med ydelser, der traditionelt har været betalt eller støttet af det offentlige. Der indgår frivillige på børnepasningsområdet, i skolerne, i ældreplejen, på hospitalsområdet, på museer osv., hvor frivillige og offentlige parter er gået sammen om i fællesskab at levere bedre velfærd til borgerne. Samtidig viser undersøgelser (bl.a. ElmoseØsterlund et al., 2017; Hjære \& Jørgensen, 2017), at der generelt er stadig flere, der anvender deres tid som frivillige særligt blandt den voksende gruppe af ældre borgere, og at flere og flere virksomheder har indarbejdet frivilligt arbejde som en del af deres "branding" på HR-området.

Dette større udbud af muligheder for at gøre en frivillig indsats på forskellige områder har medført, at nogle af de traditionelle frivillige foreninger har oplevet rekruttering af frivillige som en stadig større udfordring (Elmose-Østerlund et al., 2017). Dette sætter foreningerne under pres og betyder, at de skal finde ud af, hvordan de bedst muligt får tiltrukket de frivillige, samt hvordan de frivillige skal ledes, så de fortsat ønsker at være med.

\section{Problemfelt}

I denne artikel fokuseres der på forskningsspørgsmålet: Er det realistisk og praktisk muligt at Vi vil her fokusere på det frivillige arbejde i idrætsforeninger og anvende dette som udgangspunkt for en undersøgelse af, hvad sådanne foreninger kan gøre for i højere grad at tiltrække frivillige og fastholde dem. Ifølge Lars Kolind har "ledere af frivillige organisationer kun én mulighed: At gøre det interessant, sjovt, spændende og udviklende at være med. De frivillige skal arbejde, fordi de kan lide det” (Skårhøj \& Kappelgaard, 2011), og hvordan det kan gøres, er omdrejningspunktet for denne artikel. Det lægger op til flere spørgsmål: Hvad er det, der motiverer mennesker til at arbejde frivilligt, og hvad kan idroetsforeninger gøre for at imødekomme dette? Hvilke krav stiller det til ledelsen af foreninger, og er der sarlige forhold, der gør sig goeldende i traditionelle idrotsforeninger?

Vi undersøger betydningen af ændring i den aldersmæssige sammensætning af frivillige, hvad der motiverer de frivillige, samt hvilken betydning det har for de frivillige, hvilket formål foreningen har, og hvad der driver den. Vi vil præsentere den nyeste forskning på området og med hjælp fra forskellige ledelses- og motivationsteorier komme med bud på en ledelsesmodel, der kan anvendes til at tiltrække, fastholde og motivere frivillige i idrætsforeninger.

\section{Oversigt over artiklen}

Artiklen er opbygget i fire afsnit. Først beskrives de samfundsmæssige tendenser, der udfordrer det frivillige arbejde. Dernæst kigges der på tiltrækning af frivillige i idrætsforeninger. Det danner 
baggrund for det tredje afsnit, hvor den anvendte teori analyseres og forklares. Dette leder frem til udviklingen af vores ledelsesmodel til den frivillige leder.

\section{B. Samfundsmæssige tendenser, der udfordrer det frivillige arbejde $\mathrm{i}$ traditionelle foreninger}

\section{Den overordnede samfundsudvikling}

Udviklingen i samfundet inden for de seneste 25-30 år har stor betydning for borgeres incitament til at indgå som frivillig i forskellige sammenhænge. New Public Management (NPM), der så dagens lys i 1980erne, har på mange måder udfordret og ændret den danske velfærdsmodel. Mange institutioner er blevet til selvejende institutioner, som derved indgår i mere og mere indbyrdes direkte konkurrence, og de selvejende institutioner er taxameterfinansierede og har mulighed for og tilskyndes til at opkræve brugerbetaling samt anvende nye former for tiltrækning af finansielle og ikke-finansielle ressourcer, bl.a. anvendelse af frivillige. Dette mærkes også i de frivillige foreninger, hvor der ligeledes stilles større krav fra offentlige myndigheder med krav om afrapportering, bogholderi, overholdelse af sikkerheds-, sundheds- og miljøregler samt øget bestyrelsesansvar.

I dag bliver de traditionelle idrætsforeninger presset af nye foreninger, der tilbyder nye former for samvær. Det offentlige og private organiserer nye tiltag (Fridberg \& Henriksen, 2014), hvor man som frivillig kan gøre noget/gøre en forskel, f.eks. at være besøgsven for udsatte børn eller døende, men de frivillige motiveres også anderledes i dag end for blot 20 år siden (Bang et al., 2009; Hjære \& Jørgensen, 2017). Endvidere har måden, man udøver ledelse på i det offentlige og private ændret sig, hvilket gør, at man interagerer på en mere respektfuld og venskabelig måde med klare rammer. Dette vil man som frivillig også forvente at møde i foreningslivet.

Dette krydspres, hvor der på den ene side er mange nye muligheder for dem, der vil deltage i frivilligt arbejde, og på den anden side er øgede krav om dokumentation og kontrol, er ved at skabe en så åbenbar ubalance for de traditionelle idrætsforeninger, at der er et stigende behov for nytænkning. Dette kan stemme fint overens med den stigende individualisering i samfundet, hvor den enkelte skal have mulighed for at realisere sig selv, hvor arbejdet skal give mening og helst være sjovt og afvekslende hele tiden, men det kræver, at lederne i idrætsforeningerne tilrettelægger arbejdet og samværet, så disse kriterier bliver opfyldt.

\section{Den generelle udvikling blandt frivillige i idrætsforeninger}

En stor undersøgelse fra 2015 viser, at frivillige i idrætsforeninger bliver ældre. Andelen af frivillige trænere på 60 år eller mere er femdoblet fra fire procent i 2004 til 19 procent i 2015, mens andelen 
af 60+'ere på ledersiden er tredoblet fra ni procent i 2004 til 26 procent i 2015 som vist i figur 2 (Elmose-Østerlund et al., 2017).

Samtidig ses der en kraftig tilbagegang i andelen af frivillige i aldersgruppen 20 til 39 år, mens andelen af unge frivillige på under 20 år i samme periode har været stabil.

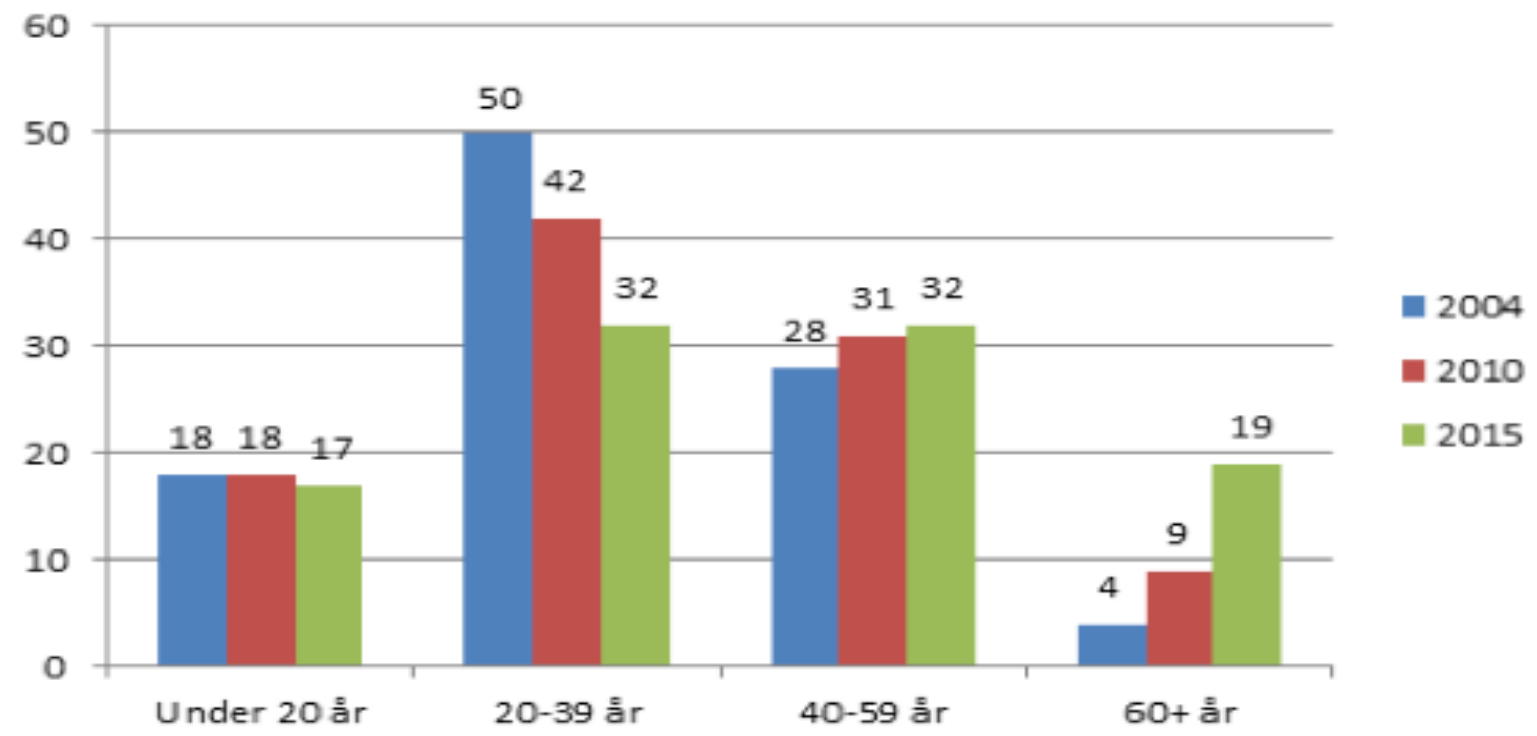

Figur 1: Fordeling af trcenere/instruktører på alder, pct. N=2822 (Elmose-Østerlund, et al., 2017)

Antallet af ledere i de forskellige aldersgrupper viser samme tendens illustreret i figur 2.:

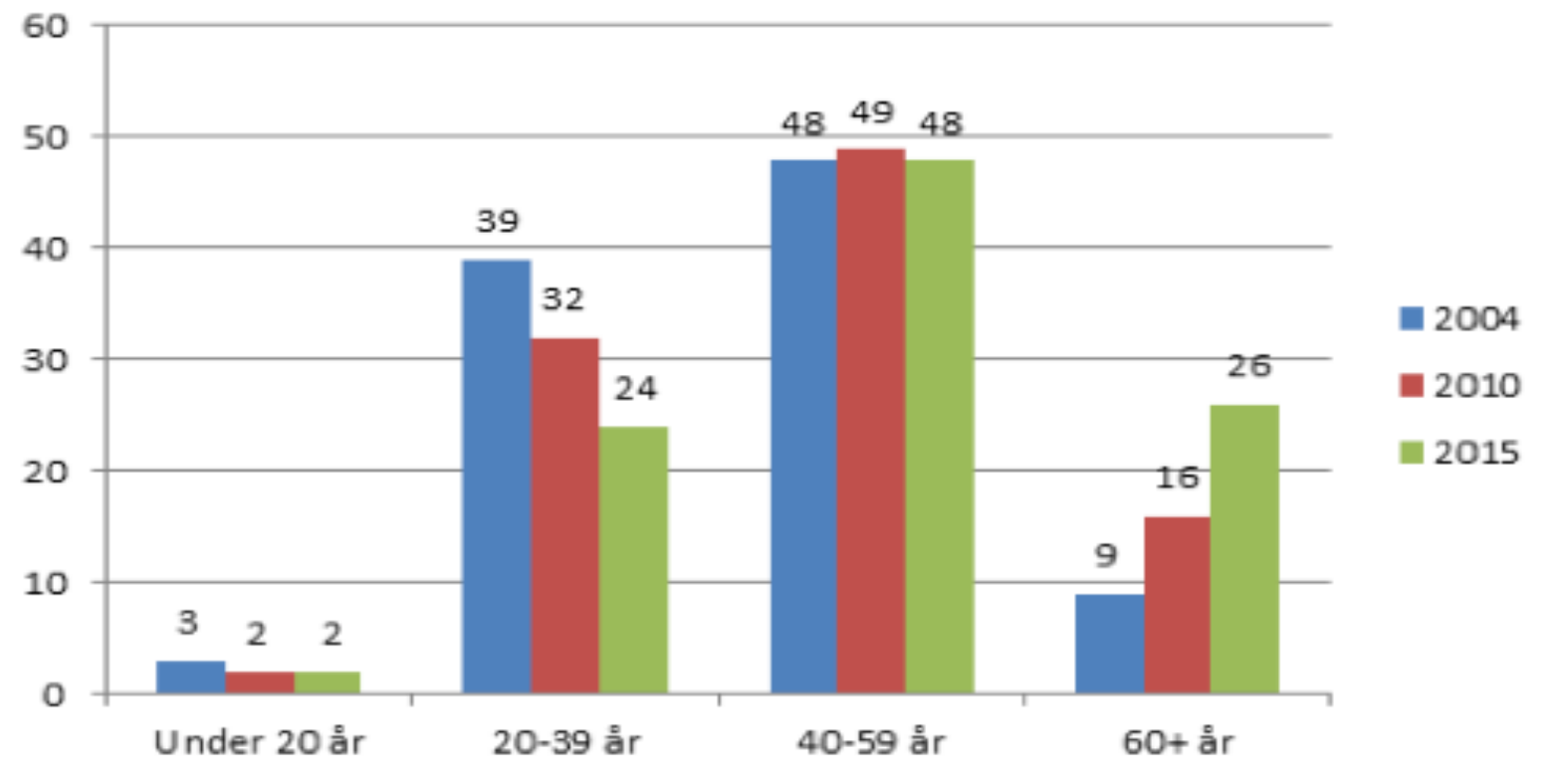

Figur 2: Fordeling af ledere på alder, pct. (Elmose-Østerlund, et al. 2017) 
Hvis denne tendens fortsætter, vil idrætsforeninger givetvis få sværere ved at få frivillige tilknyttet og måske også endnu større udfordringer med at få fastholdt og udbygget medlemstallet, da det typisk er i aldersgruppen 20-39, man stifter familie og får børn, der f.eks. går til fodbold og spejder. Selv om der generelt bliver flere ældre i samfundet, stiger antallet også blandt foreninger og andre tilbud, der måske mere målrettet appellerer til denne aldersgruppe. Denne udvikling indikerer, at idrætsforeninger med fordel bør overveje, hvordan de kan udvikle sig i en retning, der dels kan få flere mellem 20-39 år til at arbejde frivilligt, dels give de mange nye ældre frivillige det, de efterspørger som frivillige, så de ikke søger over i de mange nye tilbud. Hver 8. idrætsforening er oprettet inden for de seneste 10 år, så det er nok mest de etablerede klubber og foreninger, der har behov for nytænkning og fokusering i forhold til tiltrækning af frivillige.

Mange foreninger (ca. 22\%) gør noget særligt for at tiltrække de ældre. Det drejer sig primært om særlige idrætsaktiviteter for denne målgruppe, samt tilbud om nedsat eller gratis kontingent. I 12\% af foreningerne udgør ældre mere end 75\% af medlemmerne og kan betegnes som ældreidrætsforeninger. Tilsvarende gøres der meget for at tiltrække de unge under 20 år. 47\% af foreningerne angiver, at de har særlige initiativer for denne målgruppe.

Generelt er antallet af ældre i befolkningen mellem 2010 og 2015 øget, samtidig med at de holder sig friskere. Desuden er antallet af personer mellem 20 og 39 år i samme periode faldet. Dette kan selvfølgelig forklare noget af ændringen i fordelingen af frivillige. Samtidig er vilkårene i hverdagsog arbejdslivet for de 20-39-årige skærpet væsentligt i forhold til forventningerne til at gøre karriere og samtidig etablere familie. Derved kan det være vanskeligt at indpasse frivilligt trænerarbejde eller lederopgaver i en forening. Aldersgruppen hører dog stadig til blandt de mest aktive frivillige sammen med de 40-59-årige (Elmose-Østerlund et al., 2017).

\section{Udviklingen i, hvad der motiverer til frivilligt arbejde?}

Motivationen for at udføre frivilligt arbejde generelt har ændret sig igennem de seneste 8-10 år. Frivillighedsrapport (2012) fastslår, at det, der i særlig grad motiverer til frivilligt arbejde inden for kultur, idræt, fritid og det socialt-humanitære område, er ønsket om at hjælpe andre (46\%), at området, man er frivillig inden for, har særlig interesse i forbindelse med egen eller pårørendes personlige situation (42\%) og/eller at indgå i et fællesskab (40\%) (Center for frivilligt socialt arbejde, 2012). Det lader dog til, at dette billede er ved at blive ændret. De frivilliges motivation tenderer til at blive mere nuanceret, hvor de frivillige stiller flere krav til selvtilfredsstillelse og generelt stiller større krav til de frivillige organisationer samtidig med, at der er flere organisationer at vælge imellem. Hjære \& Jørgensen (2017) finder i deres undersøgelse (Figur 3), at det nu primært er at hjælpe andre og gøre en forskel (85\%), at have det sjovt (73\%) og at indgå i et socialt netværk og fællesskab (69\%), der motiverer mennesker til at arbejde frivilligt. 


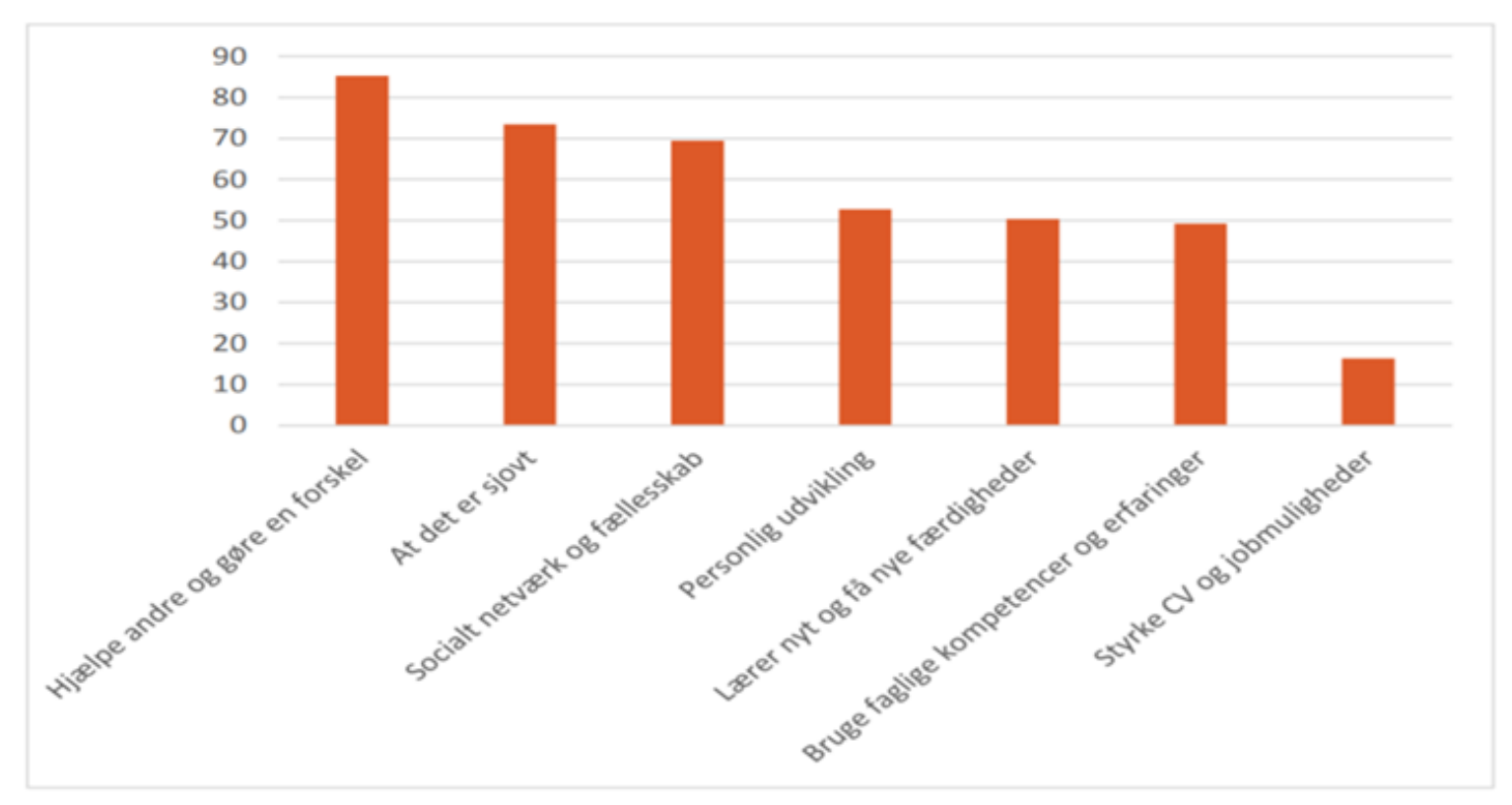

$N=4.066$. Tallene dækker både nuværende oa tidliaere frivilliae.

Figur 3: "Hvad motiverer dig i det frivillige arbejde?" Andel, der har svaret "meget stor" eller "stor" betydning. (Hjoere \& Jørgensen, 2017)

Dette stemmer overens med litteraturen specielt inden for idræt, der viser, at det er faktorer som interpersonel kontakt, kærlighed til sporten og personlig udvikling, der er nogle af de motivationsfaktorer, der får frivillige til at yde et stykke frivilligt arbejde (Bang et al., 2009). Den mest markante ændring er, at det ikke længere er nok at være interesseret i en bestemt sportsgren og indgå i et fællesskab - "det skal også være sjovt", hvilket taler ind i den tendens, der er i samfundet specielt blandt de yngre generationer, at arbejdet ikke må være kedeligt, men skal være varieret og have en form for underholdningsværdi. Der er således behov for, at lederne i idrætsforeningerne har øje for de faktorer, der tiltrækker og fastholder de frivillige, hvilket ikke er de samme for den yngre gruppe og den ældre.

\section{Tiltrækning af frivillige}

Elmose-Østerlund et al. (2017) finder i deres undersøgelse omkring frivillige i idrætsforeninger, at hovedparten af foreningerne rekrutterer nye frivillige gennem eksisterende netværk i foreningerne. Det gælder for næsten tre fjerdedele af foreningerne. Andre tiltrækningsindsatser såsom mundtlig opmuntring, fester og kvalificering (f.eks. i form af kurser) er også udbredt, idet mere end fire ud af ti foreninger angiver, at de anvender disse indsatser. Til gengæld er det få foreninger (7 pct.), der har en nedskrevet strategi for arbejdet med rekruttering og fastholdelse, selv om mange mener, at der kan være store gevinster ved at have en sådan strategi. 


\section{Formålet med foreningens virke}

Undersøgelsen viser også, at der blandt de frivillige er en stor opbakning til frivillighedsidealet. Eksempelvis er godt to tredjedele af foreningerne overvejende enige i, at foreningen bør drives udelukkende af frivillige. Desuden er formålet med at arbejde frivilligt af stor betydning for mange, selv om der er forskel på, hvilket formål der vægter mest. Figur 4 viser forskellige formåls betydning:

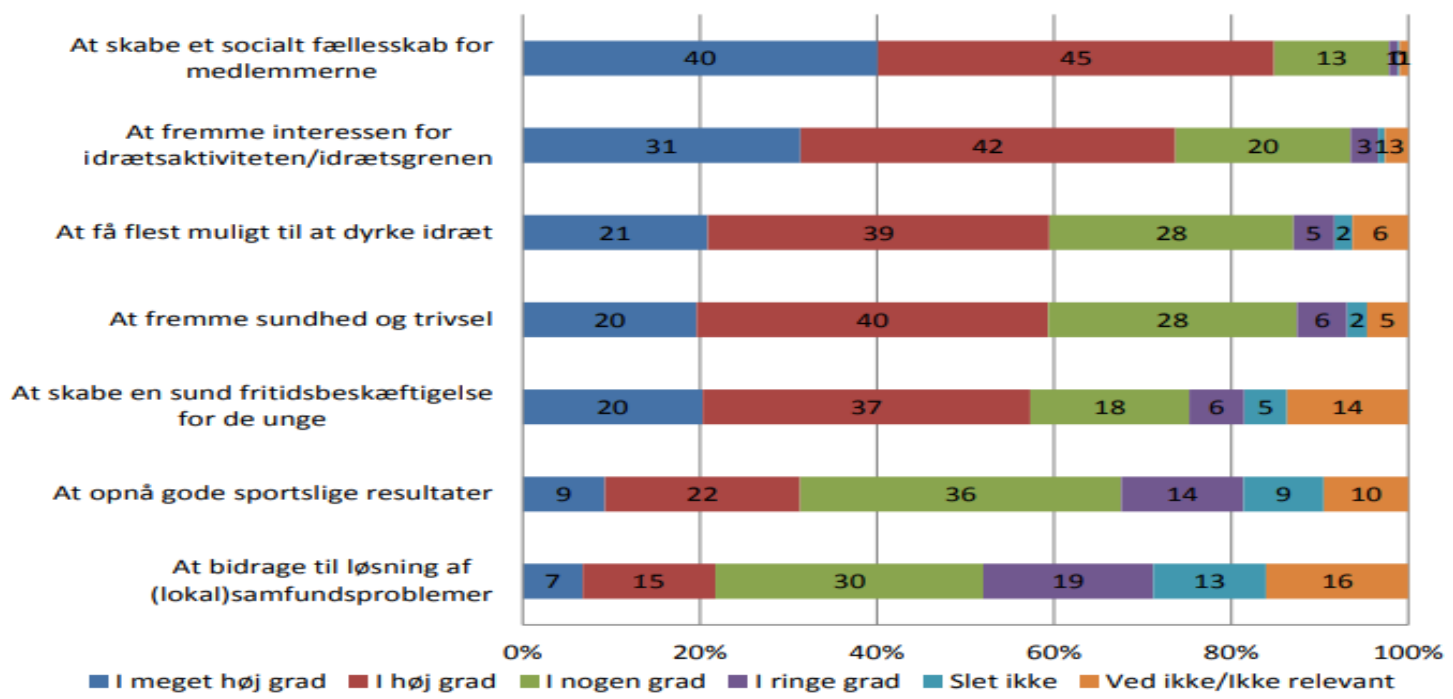

Figur 4: Foreningernes tilslutning til forskellige formål, pct. (N=2.729-2.789) (Elmose-Østerlund et al., 2017)

Hovedparten af foreningerne fokuserer mest på egne interne forhold, herunder deres medlemmer og fællesskabet foruden at fremme interessen for foreningens idrætsgren. Mindre fokus er der på, om foreningen bidrager til løsningen af (lokal)samfundsproblemer. Kun 23 pct. ser i meget høj grad eller i høj grad dette som et formål, de vægter, og kun 7 pct. synes i meget høj grad, at dette er vigtigt. Der er dog et stort antal foreninger, der finder det vigtigt at rette fokus ud mod (lokal)samfundet.

Et andet interessant område er foreningernes fokus på at opnå sportslige resultater. Foreninger fra de mindste byer/lokalsamfund svarer kun ca. hver sjette forening, at de i høj eller meget høj grad har som formål at opnå sportslige resultater. Derimod er det blandt foreninger i storbyer op imod hver tredje forening, som i høj eller meget høj grad har som vigtigt formål at opnå sportslige resultater.

Når nye frivillige skal tiltrækkes, er det således vigtigt, hvilket budskab (fællesskab eller sportslige resultater) der bliver lagt vægt på som argumentation for at arbejde frivilligt 


\section{Frivilligt arbejde i teoretisk perspektiv}

\section{Generelt}

På grund af det stadigt større antal frivillige, der bidrager med at løse mange forskellige samfundsmæssige opgaver i foreninger, er der stigende forskningsmæssig interesse omkring det frivillige arbejde i organisationer. Frivilligt arbejde kaldes forskellige ting; filantropi, altruisme, samfundsarbejde (tjeneste), frivilligt arbejde, æresopgaver osv. I 1990erne kom der en fælles forståelse af begrebet, og frivilligt arbejde blev defineret som: Frivillige aktiviteter, der er ulønnet eller betalt med et symbolsk beløb, som laves for mennesker, som er dem, der får noget ud af det, og at arbejdet har en form for formel karakter (aktiviteter er organiseret og aftalte) (Ibsen, 1992). Der er identificeret to forskellige perspektiver i forskningen omkring frivillige foreninger. Det første perspektiv fokuserer på de frivillige ud fra et individuelt niveau, hvor der fokuseres på at linke de individuelles motivationsmæssige faktorer til de frivilliges adfærd og erfaringer (Bang et al., 2009; Costa et al., 2006; Fairley et al., 2007; Farrell et al., 1998). Forskningen har fokuseret på de frivilliges erfaringer, karakteristika, motivationsfaktorer og tilfredsstillelse ved at lave frivilligt arbejde (Bang \& Chelladurai, 2009; Downward \& Ralston, 2006; Fairley et al., 2007; Kodama et al., 2013; Love et al., 2011). Frivillige i idrætsforeninger motiveres bl.a. af faktorer som formål og solidaritet, hvor formål handler om at gøre noget nyttigt og solidaritet handler om det sociale samvær, tilhørsforhold og netværk (Farrell et al., 1998). Lederne af de frivillige organisationer skal være meget bevidst om denne sammenhæng, når de organiserer aktiviteter, da det har stor betydning for de frivilliges fremtidige motivation (Kodama et al., 2013) og følelse af at have et tilhørsforhold (Costa et al., 2006).

Det andet perspektiv fokuserer på den ledelsesmæssige tilgang (management practices) på organisatorisk niveau (Cuskelly, 2004; Cuskelly et al., 2006; Downward \& Ralston, 2006; Kim et al., 2007; Doherty, 2009). På det organisatoriske niveau er det vigtigt med gode planlægningsrutiner og -værktøjer. Jo bedre en idrætsforening er til at planlægge, jo færre problemer har de med at fastholde frivillige. Det er dog stadig svært at rekruttere bestyrelsesmedlemmer og dygtige trænere (Cuskelly et al., 2006).

Forskningen har også vist betydningen af den sociale interaktion, der er imellem de frivillige (Nahapiet \& Ghoshal, 1998; Putnam, 1993), hvilket har positiv indflydelse på videndeling mellem dem, samt fordrer kommunikation og samarbejde (Putnam, 1993). Den sociale interaktion blandt frivillige betyder, at den frivillige opnår status, gruppetilhørsforhold, netværk, venskab og anerkendelse (Caldwell \& Andereck, 1994; Prestby et al., 1990). Mennesker deltager i frivilligt arbejde på grund af disse solidariske faktorer frem for materiel kompensation (Caldwell \& Andereck, 1994; Knoke \& Prensky, 1984; Prestby et al., 1990). 
Det frivillige arbejde i en idrætsforening er i sin komplicerthed betinget af sine mange interessenter og af mange målestokke for succes, hvilket kan karakteriseres som "wicked problems" (Klausen, 2014), hvor de frivillige ledere befinder sig i krydspressituationer med flertydighed og modstridende hensyn, hvilket betyder, at (strategiske) beslutninger ofte vil være præget af mange dilemmaer.

\section{Andringer i de frivilliges motivation}

Frivillige motiveres i dag stadig af altruisme og selvinteresse (Elmose-Østerlund et al., 2017; Kodama et al. 2013; Ibsen, 1992), men vi motiveres i dag også af andre forhold og på andre måder end for tyve år siden, som beskrevet i afsnittet ovenfor. Den traditionelle opfattelse - hentet fra klassisk motivationsteori - er, at vi mennesker motiveres som en helhed med ønsker, behov og valgmuligheder. En meget anvendt måde at anskue dette på er ved at tænke det som et behovshierarki, hvor (ifølge Maslow) menneskets behov kan opdeles i fem behovstyper. Disse behov er af varierende størrelse og skal opfyldes i en bestemt rækkefølge. Med udgangspunkt i behovstænkningen udviklede Herzberg en motivationsteori med udgangspunkt i lønmodtagere, hvor faktorer som jobsikkerhed, løn og forhold til kollegaer vil kunne skabe demotivation, hvis de ikke er opfyldt - de såkaldte hygiejnefaktorer. Når de grundlæggende faktorer er på plads, skal man fokusere på resultatet af arbejdet, det vil sige anerkendelse, ansvar og beslutningsret. Disse faktorer kaldes motivationsfaktorer, og kun ved at stimulere disse bliver vi som mennesker motiveret (Hein, 2013). Denne klassiske opfattelse af motivation bliver udfordret af Hein (2013), som har undersøgt motivation blandt videnmedarbejdere og kunstnere. Denne type medarbejdere synes at lægge mere vægt på at nå anerkendelse og resultater og mindre vægt på de fysiske behov. Dette mener vi også gør sig gældende for frivillige i idrætsforeninger, der på den ene side er drevet af en passion til at gøre en forskel, og på den anden side er nødt til at være træner eller spejderfører. På den baggrund mener vi, at man med fordel kan bruge Hein (2013) til at inddele de frivillige i fire mennesketyper: primadonnaer, præstationstrippere, pragmatikere og lønmodtagere. En primadonna er drevet af status og anerkendelse, en præstationstripper er drevet af resultater, en pragmatiker tænker i worklife-balance og en lønmodtager tænker i balance mellem bidrag og belønning. I tabel 1 er der en oversigt over de fire arketyper. 


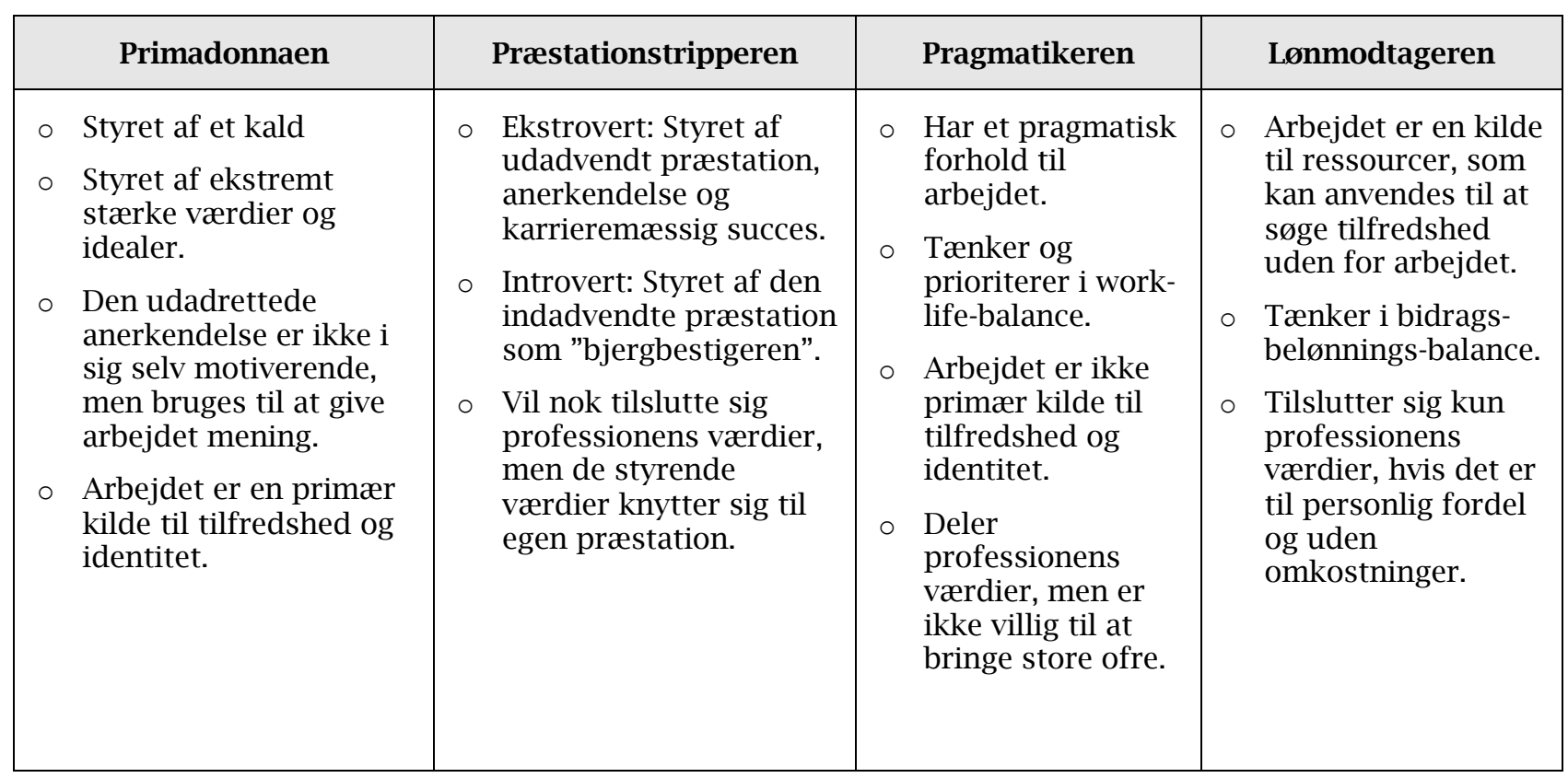

Tabel 1: Oversigt over de fire arketyper. (Hein, 2013: 197)

Der er tale om en motivationsmodel, der siger noget om, hvad der motiverer forskellige arketyper. Modellen siger ikke noget om, hvilken arketype der er bedst eller bedre end de andre, men denne tænkning omkring motivation er meget brugbar til at forsøge at gøre det spændende og interessant for frivillige, da de skal behandles/adresseres forskelligt. Der er et ordspil, der siger, at vi i dag "lever for at arbejde", hvor man tilbage i tiden "arbejdede for at leve". Det vil sige, at vores identitet er meget tættere forbundet med, hvad vi laver. Vi arbejder i dag ikke for at få dækket de grundlæggende behov som f.eks. at få noget at spise. Vi arbejder, fordi vi har fået et kald (hvis man er primadonna), eller fordi man kan opnå anerkendelse for den præstation, man laver (hvis man er præstationstripper), eller fordi det giver den rette work-life balance (hvis man er pragmatiker), eller fordi det giver de ressourcer, der er nødvendige - en personlig fordel uden for mange omkostninger (hvis man er lønmodtager). Når vi sammenligner, hvad der motiverer frivillige med Hein's (2013) arketyper, så vil frivillige typisk tilhøre primadonna- eller præstationstrippertypen eller i nogle tilfælde pragmatikeren - måske særligt, hvis der er tale om forældre, der gerne vil gøre noget for, at deres børn deltager i en eller anden form for idræt, men i øvrigt ikke er specielt interesserede i frivilligt arbejde.

Ørsted (2013) går skridtet videre og hævder, at motivationsproblemet i princippet er løst. Tidligere var der fokus på at motivere medarbejdere for at få dem til at arbejde mere. Dette er ikke problemet i dag. Produktiviteten skal stadig øges, men samtidig får flere og flere stress. Gallupundersøgelser viser, at 60 \% af danskerne har følt sig stressede det seneste år, og det tal er oppe på 78\% for folk under 35 år. Vi danskere er blandt det travleste folkefærd i verden. For 100 år siden sov man to timer mere om natten, så der handlede det om at få mennesker til at arbejde hårdere. Nu arbejder 
vi mere, end man nogensinde har gjort før. Vi er i flere timer på arbejde end nogen sinde før og flere timer end i næsten alle andre lande (Ørsted, 2013).

De sidste tyve år har vi halveret den tid, vi bruger på socialt samvær og den tid, vi bruger på at slappe af. Vi arbejder mere på jobbet, og vi laver også mere i hjemmet. Når Ørsted siger, at vi arbejder mere og mere, er det med til at forklare, at andelen af unge erhvervsaktive er faldende i idrætsforeninger, og den ældre andel er voksende. Med det øgede pres på arbejdet, bliver der mindre overskud til at tage aktiv del i de frivillige aktiviteter.

For frivillige er det ikke længere nok at få dækket behovet for at indgå i sociale relationer. Der skal noget mere til. Da vi har fået mere travlt, så kommer de frivillige ikke kun for at få en kop kaffe. De frivillige skal kunne se en mening i det, de foretager sig og skal kunne netværke for derigennem at opfylde egne mål og visioner. Samtidig skal deres børn, hvis der er tale om forældre, også have en god oplevelse, og når vi har halveret tiden, vi bruger på socialt samvær, så stiller det nye krav til, hvad de frivillige vil arbejde med og have ud af arbejdet. Idrætsforeningerne møder i dag denne nye type frivillige.

\section{3. $\quad$ Endringer i måden at lede på}

Ledelse har de senere år udviklet sig markant, og denne udvikling er vigtig at have med i de frivillige organisationer. Der er lavet mange kategoriseringer af ledelse ofte centreret omkring ledelsesstile. Disse beskrives gerne ud fra to modsatrettede poler, som f.eks. autokratisk over for laissez faire, autoritær over for kooperativ eller personorienteret over for opgaveorienteret. Lederstilene beskriver tilbøjeligheden til bestemte adfærdsmønstre, det vil sige, i hvilken retning ledelsesadfærden vil gå, og hvilke adfærdspræferencer en leder har på grundlag af sin indre indstilling. Siden Anden Verdenskrig og frem til i dag har ledelsesfokus været på produktivitet og effektivitet, og vi mennesker skulle motiveres gennem tilfredsstillelsen af optimal tilrettelæggelse af arbejdet, som så kunne retfærdiggøre en højere løn. Der er udviklet mange metoder til at engagere medarbejderne ud fra denne tilgang, og de metoder anvendes stadig i dag (Ørsted, 2013).

På et mere praktisk niveau så siger Ørsted, at ledelse er gået gennem 2 stadier og er på vej ind i det tredje stadie. Den traditionelle ledelse giver klare rammer, der er en stærk styring, der bliver gennemført med hårde midler, og kan du ikke lide "lugten i bageriet", kan du finde et andet sted at være. I moderne ledelse er forholdet mellem leder og medarbejder mere demokratisk og ligeværdigt. Lederen interesserer sig for sine medarbejdere. Der er høj grad af frihed inden for brede rammer, og særligt i forhold til måden tingene skal gøres på. I sidste ende er der dog stadig de samme krav til resultater og konsekvenser, hvis man fejler. Ifølge Ørsted er det ofte uklart, hvor ansvaret ligger, og man ender endvidere med større ansvar end indflydelse. Dette er kendetegnet ved stressede medarbejdere og en kultur, hvor man forsøger at beskytte sig selv, og hvor kreativitet og innovation 
er gået i glemmebogen. Det er nok tidens mest udbredte ledelsesform, men det er først nu, dens negative konsekvenser er ved at blive kendt. Det tredje stadie er en videreudvikling af de første to stadier: friheden inden for rammerne er stor, men der er ikke længere frihed til alt. Respekten for den enkeltes kompetencer og erfaringer bliver nu brugt til en udfordrende og inspirerende nysgerrighed, der bruges til at skifte fra overfladiske mål og præstationer til at fokusere på langsigtet bæredygtig produktion, hvor innovation er en nødvendig del af hverdagen. Tabel 2 giver et overblik over de tre ledelsesstadier.

\begin{tabular}{|l|l|l|l|}
\hline & Traditionel ledelse & Moderne ledelse & Bæredygtig Ledelse \\
\hline Virkemidler & Delegerer & Involverer & Udfordrer \\
\hline Kommunikation & Bestemmer & Overtaler & Udforsker \\
\hline Værdier & Bedrevidende & Uvidende & Nysgerrig \\
\hline Orientering & "What's in it for me?" & “What's in it for us?" & $\begin{array}{l}\text { "How can we make } \\
\text { the world better" }\end{array}$ \\
\hline Ansvar & $\begin{array}{l}\text { "Det er mit ansvar, og } \\
\text { jeg fyrer dem, der } \\
\text { ikke gør, som jeg vil } \\
\text { have!" }\end{array}$ & $\begin{array}{l}\text { "Det er dit ansvar, og } \\
\text { du bliver målt på } \\
\text { det! }\end{array}$ & $\begin{array}{l}\text { "Det er mit ansvar, } \\
\text { og de rette kan være } \\
\text { med" }\end{array}$ \\
\hline Fokus & Definerer mål & Uddelegerer mål & Skaber retning \\
\hline
\end{tabular}

Tabel 2: De tre ledelsesstadier (Ørsted, 2013: 21)

Den store udfordring for idrætsforeninger er i mange tilfælde manglende ledererfaring og kompetence. Det betyder, at mange ledere i idrætsforeninger ikke har den samme bevidsthed om, hvor vigtig ledelse er, for at få foreningen til at fungere godt, og at der i dag i langt højre grad gælder de samme mekanismer, som der gør på arbejdsmarkedet.

\section{E. Fastholdelse og ledelse af frivillige}

Et vigtigt element i forhold til fastholdelse af frivillige er måden foreningerne ledes på. Som vist i figur 5 tillægges kammeratskab og socialt samvær stor betydning. Ca. $60 \%$ af foreningerne lægger stor vægt på fællesskabet, mens 36\% i nogen udstrækning fokuserer på det. Det kan også fint hænge sammen med, at kun 45\% lægger stor eller delvis stor vægt på sportslig succes og konkurrence. 


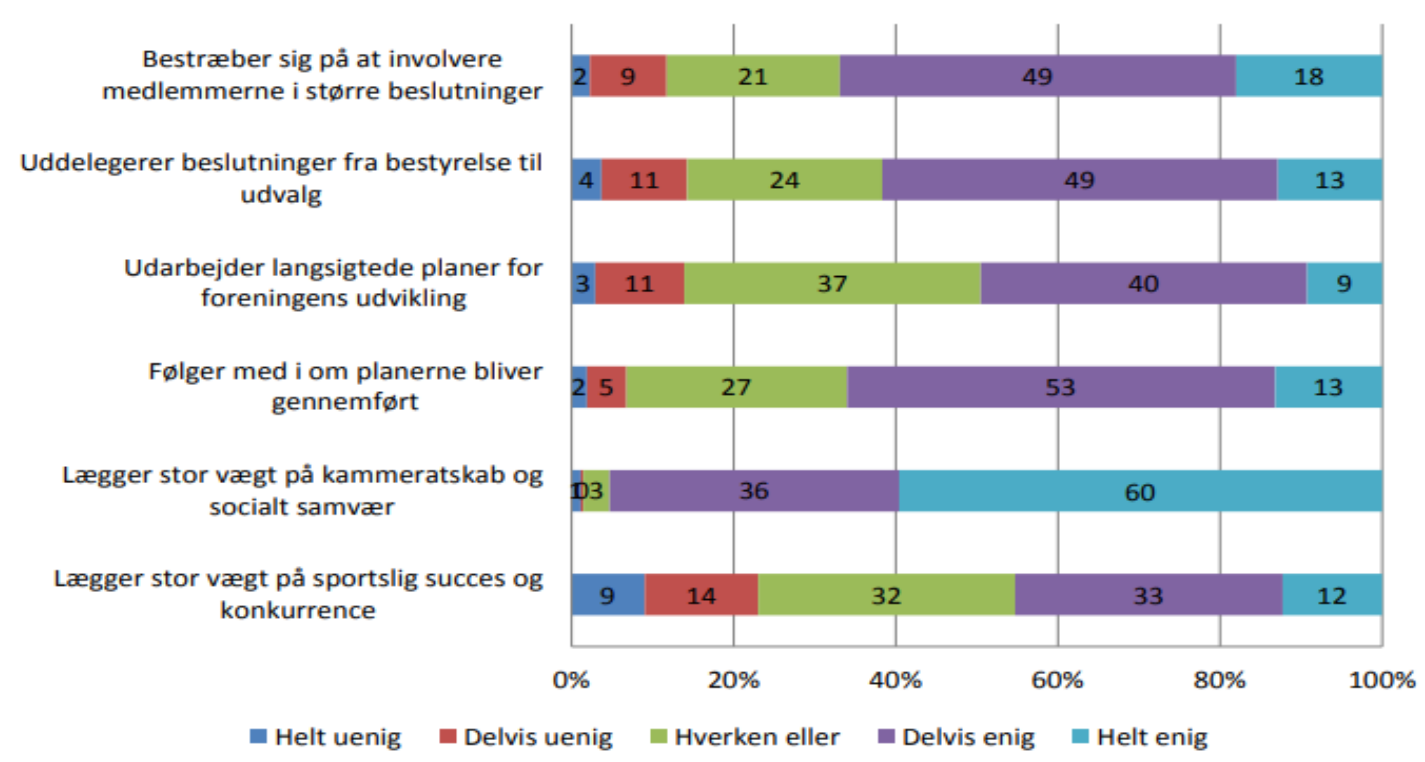

Figur 5: Holdninger i foreningernes bestyrelser til ledelse og fokus, pct. (N=2.840-2.883) (Elmose-Østerlund et al. 2017)

Andelen af foreninger, der fokuserer på involvering, er steget sammenlignet med en undersøgelse foretaget i 2010. To tredjedele af foreningerne bestræber sig på helt eller delvist at involvere medlemmerne i større beslutninger, hvilket passer godt til den demokratisk opbyggede foreningsstruktur. Jo mindre foreningerne er, des større ser involveringsgraden ud til at være. Den store involveringsgrad kan medvirke til, at de frivillige føler loyalitet og medejerskab af foreningen og dermed gøre det nemmere for foreningerne at fastholde dem. Dette stemmer også overens med resultaterne fra en analyse af sammenhængen mellem graden af involvering og foreningers arbejde med at rekruttere frivillige, der viste, at jo mere foreningerne bestræbte sig på at involvere, des lettere havde de ved at rekruttere frivillige (Østerlund, 2012).

Også uddelegering af beslutningskompetence fra bestyrelse til udvalg/frivillige er blevet øget inden for de seneste 5 år. Dette er også med til at engagere de frivillige og i øvrigt lette arbejdet for bestyrelserne. Derimod har under halvdelen af foreningerne fokus på udarbejdelse af mere langsigtede planer for foreningens udvikling. Dette tal er dog stigende med foreningernes størrelse. Med den ændrede aldersfordeling blandt de frivillige vil det sandsynligvis kræve flere ressourcer i fremtiden at rekruttere og fastholde frivillige. Derfor kan en god strategi eller plan for dette arbejde være af meget stor betydning for opretholdelsen af foreningens størrelse og eventuelt planer for vækst.

Når man kigger ovenstående udfordringer igennem, vil man kunne se, at ledelse bliver et område og en central opgave, de frivillige organisationer skal have fokus på. Med stigende krav og fokus på kontraktlige forhold til både interne og eksterne (som kommune, offentlige institutioner, sponsorer, 
medlemstilbud, etc.) aktører. Det betyder, at ledelse får en mere og mere central rolle i de frivillige organisationer, og som nævnt under ændringer i samfundstendenserne, så er der et nyt mindset under hastig udvikling blandt ledere og nøglepersoner, der også i idrætsforeninger skal slå igennem for at tiltrække og fastholde frivillige. Det skal være ledere med en mission og passion, og det er her, der er noget at hente.

Det skal være ledere, der kan få ting til at ske. Det er ledere, der har et skarpt fokus på egen rolle og en klar forståelse af, hvem der er ven og fjende, samt et skarpt fokus på, hvad der sker i verden. Dette indikerer, at det at have fokus er en nøglekompetence for ledere. Dette er nogle af de egenskaber/parametre, der kendetegner mennesker med succes og noget, der kan være med til at tiltrække andre.

Goleman (2013) argumenterer med udgangspunkt i opmærksomhedsforskningen for, at hvis man som leder skal skabe resultater, så er der brug for tre former for fokus: et indre fokus, et fokus på andre og et ydre fokus. Det indre fokus holder os i kontakt med vores intuition og grundlæggende værdier, så vi kan træffe bedre beslutninger. Det handler om at have en stærk selvbevidsthed og stærk selvledelse. Det handler om at tune ind på egne værdier, samt kende egne styrker og svagheder. Jo mere klart et indre fokus man har, des mere giver det en realistisk selvtillid, der gør det muligt at håndtere de udfordringer og distraktioner, man møder, og som gør det svært eller forhindrer os i at få opgaver løst. Et klart indre fokus sikrer, at man mobiliserer positive følelser og evnen til at komme igen efter et tilbageslag eller nederlag. Evnen kan opøves, så man endda kan komme styrket ud af tilbageslag. Fokus på andre skal sikre og forbedre kontakten til menneskene omkring os, især dem der er tæt på os. At have fokus på andre handler om at være empatisk, der gør os i stand til at se, hvordan andre har det, hvad de føler, og hvordan de opfatter ting, så man bedst muligt kan hjælpe dem. Når man kender andre personers bevæggrunde (deres mission, vision og værdier) så kan man motivere og overtale dem, og man kan øve indflydelse, samt løse konflikter og komme bedre ud af forhandlinger. Det ydre fokus hjælper os med at afkode den bredere omverden. Det handler om at fornemme og forstå de tendenser, strømninger og kræfter, der former verden omkring os både den verden, der er tæt på os, men også den, der er lidt længere væk. Det handler om at kunne aflæse de organisatoriske dynamikker, de økonomiske kræfters muligheder og begrænsninger, den teknologiske udvikling, og hvor den er på vej hen, samt de miljømæssige krav og tendenser. Et ydre fokus er en vigtig kompetence for en leder, hvis man skal kunne formulere en motiverende og visionær strategi, som andre har lyst til at være med til at realisere.

En leder, der ikke er i kontakt med sine værdier og overbevisninger, vil miste styringen. En leder, der ikke ser, hvordan andre mennesker har det, kalder Goleman for en hjælpeløs ignorant. En leder, der er ligeglad med, hvad der sker i omverdenen, går med skyklapper på og vil ende med at blive overmandet fra en blind vinkel. 
Det er ikke kun "professionelle" ledere, der kan have gavn af at have skabt balance i det indre, andre og ydre fokus. Frivillige ledere og frivillige generelt lever i samme udfordrende verden med tilværelsens konkurrerende mål og lokkemidler, og med at få tiden fordelt mellem arbejdsliv, familieliv og fritidsliv. Denne balance er under pres, som det fremgår af analysen, og det er især gældende for 20-40-årige. Det er her, de tre varianter af opmærksomhed kan hjælpe os med at skabe balance i tingene, så vi kan være produktive, få justeret inden travlhed bliver til stress, så vi kan vælge til og fra og i sidste ende være lykkelige.

Opmærksomhedsforskningen viser, at et individs opmærksomhedsevner afgør, hvor godt vi udfører en hvilken som helst opgave. Det viser, at ved veludviklede opmærksomhedsevner klarer vi os godt og modsat ved underudviklede evner, så klarer vi os dårligere (Goleman, 2013). Et bud på, hvordan man som frivillig leder skal være opmærksom på de tre opmærksomhedsområder, fremgår af tabel 3. Ifølge Goleman er det personligheder med en mission og passion, der lykkes og skaber resultater. Som frivillig skal man huske, at det er ens egen mission og passion, der er drivkræften. Uden passion - ingen mission, så det bliver meget svært at udfordre, skabe retning og motivere andre frivillige i en forening.

\begin{tabular}{|l|l|l|l|}
\hline $\begin{array}{l}\text { Ledelses- } \\
\text { forståelse }\end{array}$ & Ledelsesopgaven & Motivation & $\begin{array}{l}\text { Ledelse af de frivillige } \\
\text { i idrætsforeninger }\end{array}$ \\
\hline "Indre" fokus & $\begin{array}{l}\text { Være drevet af } \\
\text { passion og } \\
\text { engagement } \\
\text { Have en stærk } \\
\text { selvbevidsthed og et } \\
\text { stærkt drive } \\
\text { "Tune" ind på egne } \\
\text { værdier og blive } \\
\text { bevidst om egen } \\
\text { mission og passion }\end{array}$ & $\begin{array}{l}\text { Tage ansvar og finde de } \\
\text { rette frivillige }\end{array}$ & $\begin{array}{l}\text { Skabe rammer for, at } \\
\text { de frivillige føler, at de } \\
\text { gør en forskel }\end{array}$ \\
$\begin{array}{l}\text { Iværksætte initiativer, } \\
\text { der gør, at de frivillige } \\
\text { har det sjovt. Fremme } \\
\text { mulighederne for, at } \\
\text { der etableres socialt } \\
\text { netværk og fællesskab }\end{array}$ \\
\hline
\end{tabular}




\begin{tabular}{|c|c|c|c|}
\hline $\begin{array}{l}\text { Fokus på } \\
\text { andre }\end{array}$ & $\begin{array}{l}\text { Fornemme andre } \\
\text { personer (empati), } \\
\text { Sætte sig ind i andres } \\
\text { bevæggrunde } \\
\text { Øve indflydelse og } \\
\text { løse konflikter } \\
\text { Skabe retning for de } \\
\text { frivillige } \\
\text { Udfordre de frivillige. } \\
\text { Tydeliggøre ledelsens } \\
\text { ansvar }\end{array}$ & $\begin{array}{l}\text { Motivere med særlig } \\
\text { fokus på, om de } \\
\text { frivillige er } \\
\text { primadonnaer, } \\
\text { præstationstrippere } \\
\text { eller pragmatikere }\end{array}$ & $\begin{array}{l}\text { Involvere de frivillige i } \\
\text { større beslutninger. } \\
\text { Uddelegere beslut- } \\
\text { ningskompetence, men } \\
\text { fastholde eget ansvar }\end{array}$ \\
\hline "Ydre" fokus & $\begin{array}{l}\text { Fornemme og forstå } \\
\text { de kræfter, der former } \\
\text { verden } \\
\text { (organisatoriske, } \\
\text { økonomiske, } \\
\text { teknologiske og } \\
\text { miljømæssige) }\end{array}$ & $\begin{array}{l}\text { Forstå, hvad der } \\
\text { generelt driver } \\
\text { mennesker }\end{array}$ & $\begin{array}{l}\text { Mere fokus på } \\
\text { kontraktlige forhold } \\
\text { internt og eksternt } \\
\text { Udarbejde og arbejde } \\
\text { med en strategi }\end{array}$ \\
\hline
\end{tabular}

Tabel 3: Foreningslederens tre fokusområder (Egen tilvirkning)

Vi taler om, at de frivillige ledere skal ligne personligheder med en mission og en passion og skabe den rette balance i det tredobbelte fokus. Det er vigtigt, at man som frivillig leder gør sig klart, hvorfor man siger ja, hvilke bevæggrunde man har, og hvad det er, der driver én. Man skal bruge det indre fokus, når "skuden er ved at kæntre i høj søgang". En af de helt store udfordringer er, at der i idrætsforeninger er mange forskellige hensyn, der skal tages, og det er meget svært at tilgodese alle hensyn. Her kommer et stærkt indre fokus den frivillige leder til gode. Det lader til, at det, der motiverer og trækker i mennesker, er blevet mere nuanceret. Her kan Hein’s (2013) arketyper være et bud på, at man som frivillig leder kan tænke anderledes omkring at motivere de frivillige, der vil hjælpe, især med hensyn til at skabe retning og udfordre. De mange forskellige typer af frivillige betyder, at den frivillige leder skal kunne håndtere mange forskellige måder at tiltrække og motivere de frivillige, hvor udgangspunktet er at få skabt retning og udfordre de frivillige, frem for på traditionel vis at uddelegere og involvere dem. Tiltrækning og motivation af primadonnaen handler ikke om den udadrettede anerkendelse, men at tiltrække og motivere ved at det frivillige arbejde italesættes som kilden til tilfredshed, selvinteresse og identitet. Den frivillige primadonna er med til at gøre en forskel. Præstationstripperen er mere styret af at få personlig anerkendelse og vil gerne tilslutte sig idrætsforeningens værdier og formål, men de styrende værdier knytter sig til egen præstation (eller formål med aktiviteten). Pragmatikeren er egentlig ikke specielt interesseret i 
frivilligt arbejde, tænker mere i work-life-balance, hjælper gerne, hvis det er nødvendigt, men skal nok spørges fra gang til gang. Lønmodtageren er den frivillige, der kun deltager, når det er absolut nødvendigt, men kan dog overtales til at hjælpe, hvis vedkommende kan se en personlig fordel. Samlet handler fokus på andre om, at den frivillige leder med fordel kan involvere de frivillige i flere og større beslutninger samt uddelegere beslutningskompetence.

Ydre fokus handler om at kunne scanne idrætsforeningens nære og mere fjerne omgivelser, at kunne forstå og fornemme idrætsforeningens organisatoriske dynamikker, økonomiens mugligheder og begrænsninger osv. Hvis man følger tendensen, så bør fokus rettes mod, at man i idrætsforeningen i de mindre byer involverer sig i de mere lokale samfundsproblemer, mens man i større byer også har fokus på sportslige resultater. Budskabet er vigtigt, når der skal tiltrækkes frivillige, og når man skal formulere en motiverende og visionær strategi, som andre har lyst til at være en del af. Frivillige ledere kan således med fordel lade sig inspirere af alle tre former for fokus.

\section{F. Afslutning}

Ligesom på så mange andre områder i den offentlige og private sektor, så er de traditionelle idrætsforeninger kommet under et gevaldigt pres, og det er svært at tilbyde de ydelser, brugere og frivillige efterspørger. Samtidig har de traditionelle idrætsforeninger fået udfordringer fra nye foreninger. Hver tredje forening er dannet inden for de seneste 25 år, og 13\% er startet inden for de sidste 10 år (Elmose-Østerlund et al., 2017), hvilket indikerer, at man som traditionel idrætsforening skal nytænke de tilbud, man har til både brugere og frivillige. De traditionelle idrætsforeninger kommer mere og mere til at ligne traditionelle organisationer, hvilket betyder, at man som forening skal agere mere som en traditionel organisation med kontraktlige eller kontraktlignende forhold. Der er en stigende interesse for at lave frivilligt arbejde, som bl.a. handler om, at man kan gøre en forskel, og dette udfordrer de traditionelle idrætsforeninger, hvilket stiller større krav til ledelse. Disse krav handler om, at man som idrætsforening accepterer, at der skal mere fokus på ledelse og den enkelte leder. Der stilles herved større krav til, at den frivillige leder er i stand til at agere som en professionel leder, som med passion skal udleve idrætsforeningens mission, der skal omsættes til en strategi, som kan motivere de rette frivillige, ved at de udfordres og involveres $\mathrm{i}$ beslutningstagningen, at de kan se en mening i det, der foregår, indgå i nye sociale netværk og fællesskaber og samtidig have det sjovt. 


\section{Referencer}

Bang, H. \& P. Chelladurai (2009). Development and validation of the volunteer motivations scale for international sporting events (VMS-ISE). International Journal of Sport Management and Marketing, 6, 332-350. https://doi.org/10.1504/ijsmm.2009.030064

Bang, H.; D. Won \& Y. Kim (2009). Motivations, commitment, and intentions to continue volunteering for sporting events. Event Management, 13, 69-81. https://doi.org/10.3727/152599509789686317

Caldwell, L. L. \& K. L. Andereck (1994). Motives for initiating and continuing membership in a recreation-related voluntary association. Leisure Sciences, 16, 33-44.

https://doi.org/10.1080/01490409409513215

Center for frivilligt socialt arbejde (2012): Den frivillige sociale indsats. Frivilligrapport 2012.

Costa, C. A.; L. Chalip; C. B. Green \& C. Simes (2006). Reconsidering the role of training in event volunteers' satisfaction. Sport Management Review, 9, 165-182

https://doi.org/10.1016/s1441-3523(06)70024-9

Cuskelly, G. (2004). Volunteer retention in community sport organisations. European Sport Management Quarterly, 4, 59-76. https://doi.org/10.1080/16184740408737469

Cuskelly, G.; T. Taylor; R. Hoye \& S. Darcy (2006). Volunteer management practices and volunteer retention: A human resource management approach. Sport Management Review, 9, 141-163.

https://doi.org/10.1016/s1441-3523(06)70023-7

Doherty, A. (2009). The volunteer legacy of a major sport event. Journal of Policy Research in Tourism. Leisure and Events, 1, 185-207. https://doi.org/10.1080/19407960903204356

Downward, P. M. \& R. Ralston (2006). The sports development potential of sports event volunteering: Insights from the XVII Manchester Commonwealth Games. European Sport Management Quarterly, 6, 333-351. https://doi.org/10.1080/16184740601154474

Elmose-Østerlund, K.; M. R. L. Pedersen \& B. Ibsen (2017): Foreningsidrcetten anno 2015 - status og udviklingstendenser. SIVSCE Rapport. Center for forskning i Idræt, Sundhed og Civilsamfund. Syddansk Universitet

Fairley, S.; P. Kellett \& B. C. Green (2007). Volunteering abroad: Motives for travel to volunteer at the Athens Olympic Games. Journal of Sport Management, 21, 41-57.

https://doi.org/10.1123/jsm.21.1.41

Farrell, J. M.; M. E. Johnston \& G. D. Twynam (1998). Volunteer motivation, satisfaction, and management at an elite sporting competition. Journal of Sport Management, 12, 288-300.

https://doi.org/10.1123/jsm.12.4.288 
Fridberg, T. \& L. S. Henriksen (red.) (2014). Udviklingen i frivilligt arbejde 2004-2012. Det Nationale Forskningscenter for Velfoerd.

Goleman, D. (2013). Fokus - De skjulte mønstre bag unikke proestationer. Gyldendal Business.

Habermann, U. \& B. Ibsen (1998). Den frivillige sektor i Danmark - 150 års historisk udvikling. Bilag til "Frivilligt socialt arbejde i fremtidens velfoerdssamfund. Betænkning nr. 1332". Økonomi og indenrigsministeriet, 1998.

Hein, H. H. (2013). Primadonnaledelse - når arbejdet er et kald. Gyldendal Business.

Hjære, M. \& H. E. D. Jørgensen (2017). Tal om det frivillige Danmark - analyse af befolkningens frivillige engagement. En del af Frivilligrapporten 2016 - 2018. 2. udgave.

Ibsen, B. (1992). Frivilligt arbejde i idrotsforeninger [Voluntary work in sports clubs]). Systime. Denmark.

Ibsen, B. (2012). Frivilligt arbejde i idraet. Notat udarbejdet for DGI. December 2012.

Kim, M.; P. Chelladurai \& G. T. Trail (2007). A model of volunteer retention in youth sport. Journal of Sport Management, 21, 151-171.https://doi.org/10.1123/jsm.21.2.151

Kodama, E.; A. Doherty \& M. Popovic (2013). Frontline insight: An autoethnography of the Vancover 2010 volunteer experience. European Sport Management Quaterly, 13, 76-93.

https://doi.org/10.1080/16184742.2012.742123

Klausen, K. K. (2014). Strategisk ledelse i det offentlige. Gyldendal Public.

Knoke, D. \& D. Prensky (1984). What relevance do organization theories have for voluntary associations? Social Science Quarterly, 65, 3-20.

Mandag Morgen, nr. 18, (2014). De voerdifulde lederes nye verdensorden.

Nahapiet, J. \& S. Ghoshal (1998). Social capital, intellectual capital, and the organizational advantage. Academy of Management Review, 23, 242-266. https://doi.org/10.5465/amr.1998.533225

Prestby, J. E.; A. Wandersman; P. Florin; R. Rich \& D. Chavis (1990). Benefits, costs, incentive management and participation in voluntary organizations: A means to understanding and promoting empowerment. American Journal of Community Psychology, 18, 117-149.

https://doi.org/10.1007/bf00922691

Putnam, R. D. (1993). The prosperous community. The American Prospect, 4, 35-42.

Skårhøj, R. \& D. Kappelgaard (2011). Ledelse af frivillige. Ankerhus Forlag. 
Ørsted, C. (2013). Livsfarlig ledelse. People's Press.

Østerlund, K. (2012). Managing voluntary sport organizations to facilitate volunteer recruitment. European Sport Management Quarterly, 13(2), 143-165.

https://doi.org/10.1080/16184742.2012.731074 